\title{
REVIEW
}

\section{The skeletal consequences of thyrotoxicosis}

\author{
Jonathan J Nicholls, Mary Jane Brassill, Graham R Williams and J H Duncan Bassett \\ Molecular Endocrinology Group, Department of Medicine, Imperial College London, Hammersmith Campus, Room 7N2b, Commonwealth Building, Du Cane \\ Road, London W12 ONN, UK \\ (Correspondence should be addressed to J H D Bassett; Email: d.bassett@imperial.ac.uk)
}

\begin{abstract}
Euthyroid status is essential for normal skeletal development and the maintenance of adult bone structure and strength. Established thyrotoxicosis has long been recognised as a cause of high bone turnover osteoporosis and fracture but more recent studies have suggested that subclinical hyperthyroidism and long-term suppressive doses of thyroxine $\left(T_{4}\right)$ may also result in decreased bone mineral density (BMD) and an increased risk of fragility fracture, particularly in postmenopausal women. Furthermore, large population studies of
\end{abstract}

euthyroid individuals have demonstrated that a hypothalamicpituitary-thyroid axis set point at the upper end of the normal reference range is associated with reduced BMD and increased fracture susceptibility. Despite these findings, the cellular and molecular mechanisms of thyroid hormone action in bone remain controversial and incompletely understood. In this review, we discuss the role of thyroid hormones in bone and the skeletal consequences of hyperthyroidism.

Journal of Endocrinology (2012) 213, 209-221

\section{Introduction}

Thyroid hormones have a critical role in skeletal development and the maintenance of adult bone structure and strength (Williams \& Bassett 2011). Women are ten times more likely to suffer from thyroid disease and its prevalence increases with age. Between 40 and 60 years of age, the prevalence of thyrotoxicosis is $0.45 \%$; however, this increases to $1.4 \%$ after the age of 60 years. Consequently, 3\% of women over the age of 50 years receive thyroxine $\left(\mathrm{T}_{4}\right)$ replacement for either primary hypothyroidism, following radioiodine treatment or after surgery for thyrotoxicosis, and at least one-fifth of these women are over-replaced (Parle et al. 1993). Moreover, subclinical hyperthyroidism, defined as a suppressed thyroidstimulating hormone (TSH) level in the presence of normal thyroid hormone concentrations, affects an additional $1.5 \%$ of women over 60 years of age and its prevalence also increases with age. Despite the frequency of thyroid dysfunction, the role of thyroid hormone excess in the pathogenesis of osteoporosis and fracture has been under-recognised and the underlying mechanisms remain uncertain.

Osteoporosis is defined by the World Health Organisation as a bone mineral density (BMD) of 2.5 or more s.D.s below that of a young adult (T-score $\leq-2 \cdot 5)$. It is characterised by low bone mass, micro-architectural deterioration and an increased risk of fragility fracture. Osteoporosis is a global health care problem that costs $£_{\triangle} 1.7$ billion in the UK,
$\$ 15$ billion in the USA and $€ 32$ billion in Europe per annum. A personal and family history of fracture, low BMD, reduced body mass index, glucocorticoid treatment, smoking, alcohol excess and untreated thyrotoxicosis increase susceptibility to osteoporosis and fragility fracture. Furthermore, subclinical hyperthyroidism is associated with an increased risk of fracture and $\mathrm{T}_{4}$ treatment at doses sufficient to suppress TSH, resulting in increased bone turnover and low BMD in postmenopausal women (Murphy \& Williams 2004).

In this review, we describe the systemic and local regulation of thyroid hormone action, examine the role of thyroid hormone in adult bone maintenance and skeletal development and discuss the skeletal consequences of thyrotoxicosis, endogenous subclinical hyperthyroidism and prolonged suppressive $T_{4}$ treatment.

\section{Thyroid hormone physiology}

\section{The hypothalamic-pituitary-thyroid axis}

Circulating thyroid hormone concentrations are regulated by the hypothalamic-pituitary-thyroid (HPT) axis (Fig. 1). Medial neurons of the paraventricular nucleus (PVN) in the hypothalamus synthesise and secrete thyrotrophin-releasing hormone $(\mathrm{TRH})$, which in turn stimulates the synthesis and secretion of TSH from anterior pituitary thyrotrophs. TSH, acting on the TSH receptor (TSHR), stimulates thyroid 


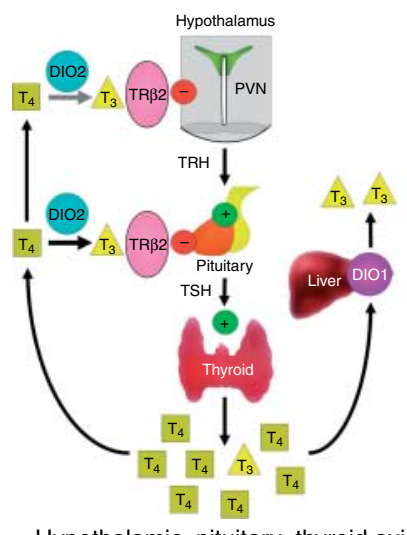

Hypothalamic-pituitary-thyroid axis

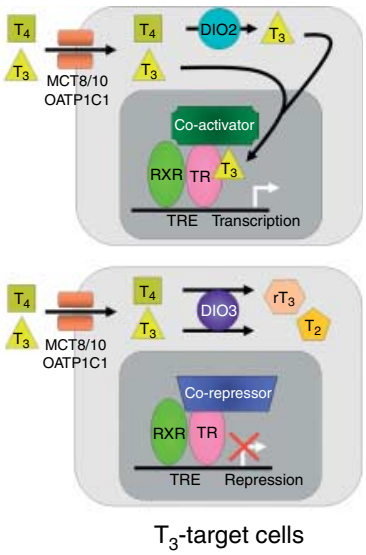

Figure 1 Systemic thyroid hormone concentrations are controlled by the negative feedback regulation of the hypothalamic-pituitarythyroid (HPT) axis. TRH stimulates the release of TSH from the anterior pituitary, which then stimulates the synthesis and secretion of $\mathrm{T}_{4}$ and $\mathrm{T}_{3}$ by the thyroid gland. DIO2 converts the pro-hormone $\mathrm{T}_{4}$ to the active hormone $\mathrm{T}_{3}$, which binds and activates TR $\beta 2$ in the hypothalamus and pituitary, resulting in the feedback inhibition of TRH production and TSH secretion. DIO1 also converts $\mathrm{T}_{4}$ to $\mathrm{T}_{3}$ in the liver, contributing to the pool of circulating $\mathrm{T}_{3}$. Thyroid hormones enter target cells via specific cell membrane transporters and intracellular supplies of $\mathrm{T}_{3}$ to the nucleus of $\mathrm{T}_{3}$-target cells are regulated by the relative activities of DIO2 and DIO3. Expression of DIO2 results in the activation of $T_{4}$ to $T_{3}$, increased intracellular $T_{3}$ concentrations and stimulation of $\mathrm{T}_{3}$-target gene transcription. Expression of DIO3 prevents the activation of $\mathrm{T}_{4}$ and inactivates $\mathrm{T}_{3}$, resulting in the repression of $\mathrm{T}_{3}$-target gene transcription. $\mathrm{PVN}$, paraventricular nucleus; $\mathrm{TRH}$, thyrotrophin-releasing hormone; $\mathrm{TSH}$, thyroid-stimulating hormone; DIO1, DIO2 and DIO3, type 1, 2 and 3 deiodinases; MCT8 and MCT10, monocarboxylate transporters 8 and 10; OATP1C1, organic acid transporter protein-1C1; TR, thyroid hormone receptor; TR $\beta 2$, thyroid hormone receptor $\beta 2 ; \mathrm{RXR}$, retinoid $\mathrm{X}$ receptor; $\mathrm{T}_{4}$, thyroxine; $\mathrm{T}_{3}, 3,5,3^{\prime}$-L-triiodothyronine; $\mathrm{rT}_{3}, 3,3^{\prime}, 5^{\prime}$-triiodothyronine; $\mathrm{T}_{2}, 3,3^{\prime}$-diiodothyronine.

follicular cell growth and the synthesis and secretion of both the pro-hormone $3,5,3^{\prime}, 5^{\prime}$-L-tetraiodothyronine $\left(\mathrm{T}_{4}\right)$ and, to a lesser extent, the active hormone $3,5,3^{\prime}$-L-triiodothyronine $\left(T_{3}\right)$. Thyroid hormones exert their effects in a wide range of peripheral tissues but also act in the PVN and pituitary to inhibit the synthesis and secretion of TRH and TSH respectively. These actions complete the physiological negative feedback loop that determines the set point for circulating thyroid hormone concentrations. Thus, the HPT axis maintains a reciprocal relationship between thyroid hormones and TSH (Bassett \& Williams 2008). The set point of the HPT axis is at least in part genetically determined with $45-65 \%$ of the inter-individual variation in serum $\mathrm{TH}$ concentrations due to genetic factors (Hansen et al. 2004, Panicker et al. 2008a, Medici et al. 2011). Accordingly, a recent genome-wide linkage scan, in dizygotic twins, identified eight quantitative trait loci associated with free $\mathrm{T}_{4}\left(\mathrm{fT}_{4}\right)$, free $\mathrm{T}_{3}\left(\mathrm{fT}_{3}\right)$ and $\mathrm{TSH}$ concentrations and an association study of 68 candidate genes involved in thyroid hormone synthesis, metabolism or transport identified a number of associations with $\mathrm{fT}_{4}$ and TSH (Panicker et al. 2008b, Medici et al. 2011). These studies have demonstrated that systemic thyroid status is inherited as a complex genetic trait and suggested that genetic heterogeneity may influence intracellular TH supply.

\section{Regulation of local intracellular $T_{3}$ supply}

$\mathrm{T}_{3}$ action in target tissues depends on the circulating concentrations of $T_{4}$ and $T_{3}$, their uptake into target cells, and local activation or inactivation (Fig. 1). The thyroid secretes mainly the pro-hormone $\mathrm{T}_{4}$ and the majority of circulating $T_{3}$ is generated in the liver and kidneys by the action of type 1 iodothyronine deiodinase enzyme (DIO1), which catalyses $5^{\prime}$-deiodination of $\mathrm{T}_{4}$. Over $95 \%$ of thyroid hormones are bound to plasma proteins and concentrations of $\mathrm{fT}_{4}$ in the circulation remain three to four times those of $\mathrm{fT}_{3}$. Cellular uptake of thyroid hormones is mediated by specific membrane transporters, which include monocarboxylate transporters (MCT8 (SLC16A2) and MCT10 (SLC16A10)) and organic acid transporter protein-1C1 (OATP1C1 (SLCO1C1); van der Deure et al. 2010). The intracellular availability of $\mathrm{T}_{3}$ is determined by the relative activities of DIO2 and DIO3 (Bianco \& Kim 2006, St Germain et al. 2009). DIO2 converts the pro-hormone $T_{4}$ to the active hormone $\mathrm{T}_{3}$ by the removal of an outer-ring $5^{\prime}$-iodine atom, whereas DIO3 inactivates $T_{3}$ and prevents the activation of $T_{4}$ by the removal of an inner-ring 5-iodine atom to produce the inactive metabolites $3,3^{\prime}, 5^{\prime}$-L-triiodothyronine (reverse- $\mathrm{T}_{3}$ ) and $3,3^{\prime}$-diiodotyrosine ( $\mathrm{T}_{2}$; Bianco \& Kim 2006). DIO2 activity is regulated by a rapid post-translation mechanism involving $\mathrm{T}_{4}$-induced ubiquitin-mediated proteasomal degradation (Gereben et al. 2008). Thus, in hypothyroidism, DIO2 activity is increased, and in thyrotoxicosis, it is reduced. By contrast, D3 expression and activity is increased in thyrotoxicosis and reduced in thyroid hormone deficiency. Thus, the relative local expression of DIO2 and DIO3 represents a homeostatic mechanism that regulates target tissue responses to thyroid hormone (Gereben et al. 2008).

\section{Thyroid hormone action}

Thyroid hormone action is mediated by thyroid hormone receptors (TRs), nuclear receptors which act as hormoneinducible transcription factors, in association with coregulatory proteins (Fig. 1). Unliganded TRs associate with co-repressor proteins and bind thyroid hormone response elements, in the promoter region of target genes, to mediate transcriptional repression. $\mathrm{T}_{3}$ binding results in a conformational change, dissociation of co-repressors and recruitment of co-activators, resulting in chromatin modification and the activation of gene transcription (Yen 2001, Cheng et al. 2010). TRs are encoded by two genes, THRA and THRB, from which multiple $\operatorname{TR} \alpha$ and $\operatorname{TR} \beta$ isoforms are transcribed. TR $\alpha 1, T R \beta 1$ and TR $\beta 2$ contain DNA and ligand-binding domains and are functional receptors, whereas 
TR $\propto 2$ lacks hormone-binding activity and acts as a weak antagonist in vitro. The truncated isoforms $\operatorname{TR} \Delta \alpha 1$ and $\operatorname{TR} \Delta \alpha 2$ cannot bind DNA but play a developmental role in the gut epithelium (Plateroti et al. 2001). TR $\alpha 1$, TR $\alpha 2$ and TR $\beta 1$ are widely expressed in a tissue-specific and temporospatial manner (Forrest et al. 1990). TR $\beta 2$ is primarily expressed in the hypothalamus and pituitary, where it mediates the negative feedback regulation of TRH and TSH (Abel et al. 2001). Both TR $\alpha 1$ and TR $\beta 1$ are expressed in skeletal cells but TR $\alpha 1$ is expressed at tenfold higher levels than TR $\beta 1$ (O'Shea et al. 2003, Bookout et al. 2006). Accordingly, detailed phenotyping of a series of mice with a mutation or deletion of the Thra or Thrb genes demonstrated that $\mathrm{TR} \alpha 1$ is the key mediator of $\mathrm{T}_{3}$ action in bone (Gauthier et al. 2001, O'Shea et al. 2003, 2005, Bassett et al. 2007a,b, Bassett \& Williams 2009). Thus, despite systemic euthyroidism, Thra (TR $\alpha)$-mutant mice display features of impaired thyroid hormone action in bone, with delayed skeletal development and increased bone mass together with impaired bone remodelling in adulthood (Gauthier et al. 2001, O'Shea et al. 2003, 2005, Bassett et al. 2007a,b, Bassett \& Williams 2009). Furthermore, the elevated circulating $T_{3}$ and $T_{4}$ concentrations in Thrb (TR $\beta)$-mutant mice, which are a consequence of the disruption of the HPT axis, result in the supra-physiological stimulation of TR $\alpha 1$ in bone and advanced skeletal development but adult osteoporosis due to increased bone remodelling (Gauthier et al. 2001, O'Shea et al. 2003, 2005, Bassett et al. 2007a,b, Bassett \& Williams 2009). Although the study of global mutant mice has advanced the understanding of thyroid hormone action in bone, such approaches cannot identify the in vivo cell targets of $\mathrm{T}_{3}$ action and the application of cell-specific gene-targeting strategies is now required.

\section{Skeletal development}

During endochondral ossification, mesenchyme-derived chondrocytes synthesise a cartilage model of each skeletal element termed an anlage. Hypertrophic differentiation begins at the centre of the anlage and is followed by apoptosis, initiating the formation of the primary ossification centre. Hypertrophic chondrocytes synthesise type X collagen, which induces cartilage mineralisation, thus generating a template for osteoblastic bone formation. Epiphyseal growth plates form at either end of the anlage and consist of organised columns of proliferating, differentiating and apoptosing chondrocytes. Chondrocyte enlargement during hypertrophic differentiation results in linear growth and the production of a mineralised cartilage template upon which the trabecular bone is formed. At the edges of the growth plate, perichondrial cells of mesenchymal origin differentiate into bone-forming osteoblasts and synthesise a bone collar, which subsequently becomes the cortical bone. $\mathrm{T}_{3}$ is an important regulator of skeletal development and linear growth. Childhood hypothyroidism results in growth arrest, delayed bone age and a severe disruption of the growth plate architecture (Rivkees et al. 1988, Boersma et al. 1996, Huffmeier et al. 2007). By contrast, juvenile thyrotoxicosis accelerates growth and advances bone age.

\section{The bone remodelling cycle}

Functional integrity and strength of the adult skeleton is maintained by a continuous process of repair called 'the bone remodelling cycle' (Raggatt \& Partridge 2010). This highly synchronised process occurs in basic multicellular units, which comprise osteocytes, osteoclasts and osteoblasts localised within the bone remodelling cavity (Fig. 2). The bone remodelling cycle has a duration of 150-200 days and is characterised by sequential periods of activation, bone resorption, reversal, bone formation and quiescence. Activation of the bone remodelling cycle is initiated by local structural damage, altered mechanical loading mediated by osteocytes embedded within the bone, or by changes in systemic or paracrine factors. Osteocytes are embedded within the bone and connected by a complex network of dendritic processes that is thought to act as the primary skeletal mechano-transducer. Under basal conditions, osteocytes secrete transforming growth factor $\beta$ (TGF $\beta$ ) and sclerostin, which inhibit osteoclastogenesis and Wnt-activated osteoblastic bone formation respectively. Increased load or local micro-damage results in a fall in local TGF $\beta$ levels (Heino et al. 2002) and the activation of bone lining cells leads

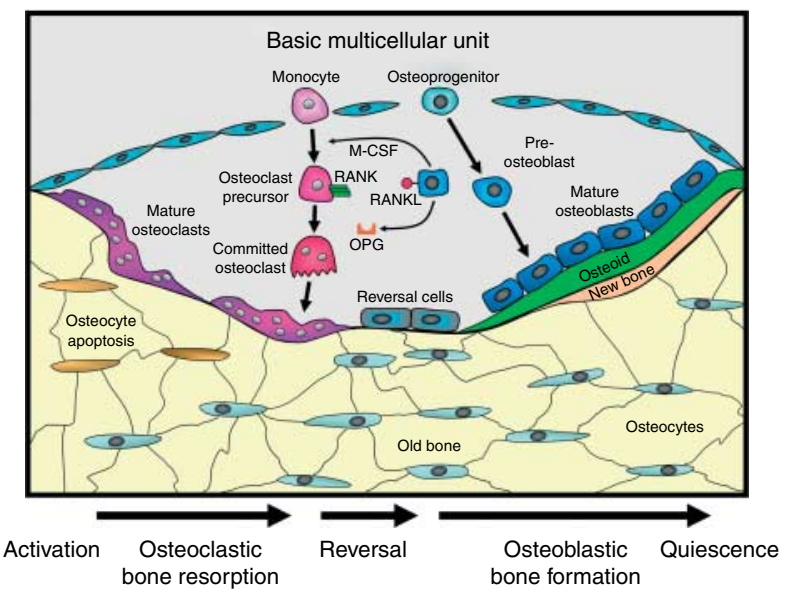

Figure 2 Schematic representation of the basic multicellular unit of the bone remodelling cycle. The bone remodelling cycle is initiated and orchestrated by osteocytes, which are embedded within mineralised bone and communicate via ramifications of dendritic processes. Bone remodelling may result from changes in mechanical load, structural damage or exposure to systemic or paracrine factors. Haemopoietic cells of the monocyte/macrophage lineage differentiate to mature osteoclasts and resorb bone. During the reversal phase, osteoblastic progenitors are recruited to the site of resorption, differentiate and synthesise osteoid, and mineralise the new bone matrix to repair the defect. Crosstalk between boneforming osteoblasts and bone-resorbing osteoclasts regulates bone remodelling and maintains skeletal homeostasis. M-CSF, macrophage colony-stimulating factor; OPG, osteoprotegerin; RANK, receptor activator of NFKB; RANKL, RANK ligand. 
to the recruitment of osteoclast progenitors. Osteocytes and bone lining cells express monocyte/macrophage colonystimulating factor (M-CSF) and receptor activator of nuclear factor $\kappa \mathrm{B}(\mathrm{NF} \kappa \mathrm{B})$ ligand $(\mathrm{RANKL})$, the two cytokines required for the formation of mature multi-nucleated boneresorbing osteoclasts (Raggatt \& Partridge 2010, Nakashima et al. 2011). Osteoclasts adhere to the bone surface, creating a sealed micro-environment into which they secrete acid and proteases that demineralise and degrade the bone matrix. Following the resorption phase, which lasts 30-40 days, reversal cells remove undigested matrix fragments from the bone surface, and local paracrine signals derived from the degraded matrix result in osteoblast recruitment and the initiation of the bone formation phase. Over the following 150 days, mature osteoblasts secrete and mineralise the new bone matrix (osteoid) to fill the resorption cavity. When the repair is complete, bone formation ceases and the surface returns to its quiescent state covered with bone lining cells. This continual process of targeted bone remodelling enables the adult skeleton to repair old or damaged bone, react to changes in mechanical stress and respond rapidly to the demands of mineral homeostasis. However, to ensure that skeletal integrity is maintained, the processes of bone resorption and formation must be regulated tightly. Despite this, the nature of the coupling process remains controversial and involves both systemic and local factors (Raggatt \& Partridge 2010). In adults, thyroid hormone deficiency results in reduced bone turnover and a prolongation of the bone remodelling cycle (Melsen \& Mosekilde 1980, Eriksen et al. 1986) and is associated with a two- to threefold increase in fracture risk (Vestergaard \& Mosekilde 2002). By contrast, established thyrotoxicosis is a recognised cause of high bone turnover osteoporosis and fragility fracture (Vestergaard \& Mosekilde 2003).

\section{Direct actions of TSH in skeletal cells}

TSHR is expressed predominantly in thyroid follicular cells, where it regulates proliferation and thyroid hormone synthesis and secretion. However, its expression has also been described in other tissues including the brain, heart, kidney, testis, adipose tissue, pituitary and immune and haemopoietic cells (Davies et al. 2002). The demonstration of TSHR expression in osteoblasts and osteoclasts suggested that TSH might have direct actions in bone (Abe et al. 2003). Studies of juvenile $T s h r$-knockout mice $\left(T s h r^{-/}\right)$, with treated congenital hypothyroidism, identified a phenotype of high bone turnover osteoporosis. Furthermore, in vitro analysis indicated that TSH inhibited both osteoclast and osteoblast activity (Abe et al. 2003). These findings led to the proposal that TSH was a key negative regulator of bone turnover and that bone loss associated with thyrotoxicosis was a consequence of TSH deficiency rather than thyroid hormone excess (Abe et al. 2003). Subsequent studies, however, suggested that TSH enhanced (Sampath et al. 2007,
Sun et al. 2008) or had no effect (Bassett et al. 2008) on osteoblast differentiation and function while actions in osteoclasts were either absent (Bassett et al. 2008) or inhibitory (Hase et al. 2006, Sampath et al. 2007, Sun et al. 2008).

To determine the relative importance of $\mathrm{T}_{3}$ and $\mathrm{TSH}$ in bone, the skeletal phenotypes of two mouse models of congenital hypothyroidism were analysed. Hyt/hyt mice have a Tshr loss-of-function mutation resulting in congenital hypothyroidism with a 2000-fold increase in TSH, whereas Pax $8^{-1-}$ mice have an intact $T$ shr but have congenital hypothyroidism due to thyroid follicular cell agenesis and a similar 2000-fold increase in TSH (Bassett et al. 2008). Thus, $H y t / h y t$ mice lack all TSHR signalling, whereas in $\mathrm{Pax} 8^{-/-}$ mice, it is maximal. The similar skeletal phenotype in $H y t / h y t$ and $\mathrm{Pax} 8^{-1-}$ mice thus indicates that the HPT axis regulates skeletal development via the actions of $\mathrm{T}_{3}$ rather than TSH. Furthermore, TSH treatment of osteoblasts and osteoclasts in vitro does not induce the canonical TSHR secondary messenger cAMP (Tsai et al. 2004, Bassett \& Williams 2008) and levels of TSHR protein expression were very low relative to thyroid follicular cells (Bassett \& Williams 2008). These findings suggest that changes in TNF $\alpha$, RANKL, OPG and interleukin 1 signalling reported in response to TSH may be mediated via an alternative G-protein (Abe et al. 2003, Hase et al. 2006, Ma et al. 2011). Indeed, intermittent TSH treatment of rodents, at doses insufficient to affect thyroid status, resulted in anti-resorptive and anabolic responses sufficient to prevent ovariectomy-induced bone loss (Sampath et al. 2007, Sun et al. 2008).

Subsequently, the role of thyroid hormone excess and TSH deficiency have been variously emphasised in clinical studies investigating the relationship between thyroid status, BMD and fracture (Bassett \& Williams 2008, Murphy et al. 2010, Roef et al. 2011). However, since there is a physiological reciprocal relationship between thyroid hormones and TSH, studies of individuals with an intact HPT axis cannot discriminate the skeletal effects of thyroid hormone excess and TSH deficiency. To address this issue, the effects of recombinant human TSH (rhTSH) on bone turnover markers have been studied in women with thyroid cancer receiving suppressive doses of $\mathrm{T}_{4}$. As these patients had previously undergone total thyroidectomy, the rhTSH treatment did not affect $\mathrm{T}_{4}$ and $\mathrm{T}_{3}$ concentrations but increased serum TSH concentrations to $>100 \mathrm{mU} / \mathrm{l}$. rhTSh was found to have no effect on bone formation or resorption markers in pre-menopausal women (Mazziotti et al. 2005, Giusti et al. 2007, Martini et al. 2008). Results in postmenopausal women have been contradictory: two of four studies reported increased bone formation markers and reduced bone resorption markers in response to hTSH, whereas two studies showed no effect (Mazziotti et al. 2005, Giusti et al. 2007, Martini et al. 2008, Karga et al. 2010). Finally, a study of two siblings with isolated TSH deficiency, who had received $T_{4}$ replacement from birth, reported that 
BMD and bone turnover markers were normal despite the absence of TSH (Papadimitriou et al. 2007).

In summary, TSH has been proposed as a direct negative regulator of bone turnover. Although, osteoblasts and osteoclasts have been shown to express low levels of TSHR protein, TSH does not induce the canonical secondary messenger cAMP. TSH treatment of cultured osteoblasts and osteoclasts has yielded conflicting results but despite this, studies of intermittent low-dose TSH treatment prevented ovariectomy-induced bone loss in mice.

\section{Skeletal consequences of thyrotoxicosis}

Established thyrotoxicosis has long been recognised to have detrimental consequences for both the developing and adult skeleton, including permanent short stature, osteoporosis and increased fracture risk (von Recklinghausen 1891). More recently, the effects of subclinical hyperthyroidism, suppressive $\mathrm{T}_{4}$ treatment and thyroid status in the upper normal range on BMD and fracture risk have been investigated (Table 1).

\section{Thyrotoxicosis in childhood}

Thyrotoxicosis in childhood is rare but most commonly caused by Graves' disease. Juvenile thyrotoxicosis results in accelerated growth and advanced bone age, and in severe early cases it can cause premature fusion of the growth plates and cranial sutures resulting in persistent short stature and craniosynostosis (Segni et al. 1999). By contrast, childhood hypothyroidism results in growth arrest, delayed bone age and a severe disruption of the growth plate architecture (Rivkees et al. 1988, Boersma et al. 1996, Huffmeier et al. 2007). $\mathrm{T}_{3}$ excess accelerates the pace of growth plate chondrocyte differentiation via actions on the key Indian hedgehog/ parathyroid hormone-related peptide, bone morphogenetic protein, fibroblast growth factor (FGF), growth hormone (GH), insulin-like growth factor 1 (IGF1) and canonical Wnt signalling pathways (Robson et al. 2000, Stevens et al. 2000, Barnard et al. 2005, Dentice et al. 2005, O'Shea et al. 2005, Lassova et al. 2009, Wang et al. 2010, Xing et al. 2012). In addition, $\mathrm{T}_{3}$ acts to accelerate cartilage matrix synthesis, modification, mineralisation and degradation (Ishikawa et al. 1998, Robson et al. 2000, Himeno et al. 2002, Makihira et al. 2003, Bassett et al. 2006).

\section{Thyrotoxicosis in adults}

Prompt diagnosis and treatment of thyroid disease means that severe uncontrolled thyrotoxicosis is now rarely encountered but it is an established cause of high bone turnover osteoporosis and fragility fracture (Vestergaard \& Mosekilde 2003). Population and case-control studies have demonstrated that a prior history of hyperthyroidism is an independent risk factor for hip and vertebral fracture (Cummings et al. 1995, Wejda et al. 1995, Seeley et al. 1996, Bauer et al. 2001, Vestergaard et al. 2005, Ahmed et al.
2006). A meta-analysis of 25 studies showed that BMD was decreased and fracture risk increased in untreated hyperthyroidism (Vestergaard \& Mosekilde 2003). Hyperthyroidism was associated with a relative risk of hip fracture of $1 \cdot 6$, with the risk increasing significantly with age. A prospective cohort study of postmenopausal women demonstrated that hyperthyroidism was associated with a three- to fourfold increase in fracture and this was only in part due to reduced BMD, suggesting that hyperthyroidism may result in both reduced mineralisation and impaired bone quality (Bauer et al. 1997, 2001).

Histomorphometric analysis has shown that thyrotoxicosis results in an increased frequency of bone remodelling cycle initiation and a shortened cycle duration. The bone formation phase is reduced to a greater extent than the resorption phase, leading to a $10 \%$ loss of bone per cycle (Mosekilde \& Melsen 1978, Eriksen et al. 1986). Furthermore, increases in biochemical markers of bone resorption (urinary cross-linked N-telopeptides pyridinoline of type I collagen, pyridinoline and deoxypyridinoline collagen crosslinks and hydroxyproline) and bone formation (carboxyterminal propeptide of type 1 collagen, serum alkaline phosphatase and osteocalcin) correlate with disease severity (Harvey et al. 1991, Garnero et al. 1994, Guo et al. 1997, Toivonen et al. 1998). By contrast, hypothyroidism results in reduced bone turnover with a prolongation of the bone remodelling cycle (Melsen \& Mosekilde 1980, Eriksen et al. 1986) but hypothyroidism is similarly associated with a two- to threefold increase in fracture risk (Vestergaard \& Mosekilde 2002, Vestergaard et al. 2005). Despite these observations, understanding of the molecular mechanisms by which thyroid hormones regulate the bone remodelling cycle remains incomplete. Indeed, although osteoclastic bone resorption is increased in individuals with thyrotoxicosis (Mosekilde $e t$ al. 1990), in vitro studies of osteoclast and osteoblast/osteoclast co-culture have failed to resolve whether $\mathrm{T}_{3}$ acts directly in osteoclasts or whether its actions are indirect and mediated by the effects in osteoblasts (Mundy et al. 1976, Allain et al. 1992, Britto et al. 1994, Kanatani et al. 2004). Nevertheless, $T_{3}$ has been shown to accelerate osteoblast differentiation directly, resulting in increased osteoid matrix synthesis and mineralisation, thus regulating bone mineralisation and strength (Huang et al. 2000, Stevens et al. 2003, Bassett et al. 2010). Accordingly, in osteoblast cultures, $\mathrm{T}_{3}$ enhances the expression of type I collagen and markers of osteoblast differentiation including osteocalcin, osteopontin and alkaline phosphatase, while also regulating FGF receptor 1 and IGF1 signalling pathways (Huang et al. 2000, Stevens et al. 2003).

\section{Thyrotoxicosis and mineral homeostasis}

Thyrotoxicosis is associated with a significant negative calcium balance (Mosekilde et al. 1990, Harvey \& Williams 2002) but despite this, hypercalcaemia may occur in up to $20 \%$ of hyperthyroid patients. The high bone turnover results in increased mobilisation of calcium from the skeleton and the 
Table 1 Summary of large studies and meta-analyses

\begin{tabular}{|c|c|c|c|c|c|}
\hline Year & Study type & Population & Numbers & Summary of findings & Reference \\
\hline \multicolumn{6}{|c|}{ Studies of individuals with abnormal thyroid function } \\
\hline 1992 & Thyroid registry & $\begin{array}{l}\mathrm{T}_{4} \text {-treated pre- and post- } \\
\mathrm{MW} \text { and men }\end{array}$ & 1180 individuals & $\begin{array}{l}\text { No increased fracture risk associ- } \\
\text { ated with suppressed TSH }\end{array}$ & Leese et al. (1992) \\
\hline 1994 & Meta-analysis & Pre- and post-MW & 13 studies of BMD & $\begin{array}{l}\text { Reduced BMD in post-MW } \\
\quad \text { associated with suppressed TSH }\end{array}$ & $\begin{array}{l}\text { Faber \& Galloe } \\
\quad(1994)\end{array}$ \\
\hline 1995 & $\begin{array}{l}\text { 4-year prospective } \\
\text { study }\end{array}$ & Post-MW > 65 years old & 9516 individuals & $\begin{array}{l}\text { History of TTX associated with an } \\
\text { increased risk of hip fracture }\end{array}$ & $\begin{array}{l}\text { Cummings et al. } \\
\text { (1995) }\end{array}$ \\
\hline 1996 & Meta-analysis & $\begin{array}{l}\mathrm{T}_{4} \text { treatment of pre- and } \\
\text { post-MW and men }\end{array}$ & 33 studies of BMD & $\begin{array}{l}\text { Suppressive } \mathrm{T}_{4} \text { treatment associ- } \\
\text { ated with reduced BMD in } \\
\text { post-MW }\end{array}$ & Uzzan et al. (1996) \\
\hline 1998 & Thyroid registry & $\begin{array}{l}\text { Radioiodine-treated TTX in } \\
\text { women and men }\end{array}$ & 7209 individuals & $\begin{array}{l}\text { Increased risk of fracture and } \\
\text { mortality }\end{array}$ & $\begin{array}{l}\text { Franklyn et al. } \\
\text { (1998) }\end{array}$ \\
\hline 2000 & $\begin{array}{l}\text { Retrospective } \\
\text { cohort }\end{array}$ & $\begin{array}{l}\text { Thyrodectomy-treated TTX } \\
\text { in women }\end{array}$ & 630 individuals & No increase in overall fracture risk & Melton et al. (2000) \\
\hline 2001 & $\begin{array}{l}\text { 4-year prospective } \\
\text { cohort study }\end{array}$ & Post-MW & 686 individuals & $\begin{array}{l}\text { Suppressed TSH associated with an } \\
\text { increased risk of hip and } \\
\text { vertebral fracture }\end{array}$ & Bauer et al. (2001) \\
\hline 2002 & Literature review & $\begin{array}{l}\text { Subclinical hyperthyroid- } \\
\text { ism in pre- and post-MW } \\
\text { and men }\end{array}$ & 11 studies of BMD & $\begin{array}{l}\text { No effect of subclinical hyper- } \\
\text { thyroidism in pre-MW and men }\end{array}$ & Quan et al. (2002) \\
\hline 2003 & Meta-analysis & $\begin{array}{l}\text { Hyperthyroidism in pre- } \\
\text { and post-MW and men }\end{array}$ & $\begin{array}{l}20 \text { studies of BMD } \\
\text { and five studies of } \\
\text { fracture }\end{array}$ & $\begin{array}{l}\text { BMD reduced and fracture risk } \\
\text { increased in TTX }\end{array}$ & $\begin{array}{l}\text { Vestergaard \& } \\
\quad \text { Mosekilde (2003) }\end{array}$ \\
\hline 2004 & Literature review & $\begin{array}{l}\text { Thyroid disease in pre- and } \\
\text { post-MW and men }\end{array}$ & $\begin{array}{l}24 \text { studies of BMD } \\
\text { and } 13 \text { studies of } \\
\text { fracture }\end{array}$ & $\begin{array}{l}\text { Suppressed TSH associated with an } \\
\text { increased risk of fracture }\end{array}$ & $\begin{array}{l}\text { Murphy \& Williams } \\
\text { (2004) }\end{array}$ \\
\hline 2005 & $\begin{array}{l}\text { Cross-sectional } \\
\text { study }\end{array}$ & $\begin{array}{l}\text { Post-MW (fracture inter- } \\
\text { vention trial) }\end{array}$ & 15316 individuals & $\begin{array}{l}\text { Osteoporosis and vertebral fracture } \\
\text { associated with low TSH }\end{array}$ & Jamal et al. (2005) \\
\hline 2005 & $\begin{array}{l}\text { Case-control } \\
\text { study }\end{array}$ & $\begin{array}{l}\text { Women and men with } \\
\text { fracture }\end{array}$ & $\begin{array}{c}124655 \text { individuals, } \\
373962 \text { controls }\end{array}$ & $\begin{array}{l}\text { Increased risk of fracture for } 5 \text { years } \\
\text { after diagnosis of TTX }\end{array}$ & $\begin{array}{l}\text { Vestergaard et al. } \\
\text { (2005) }\end{array}$ \\
\hline 2006 & Literature review & $\begin{array}{l}\text { Suppressive } \mathrm{T}_{4} \text { therapy in } \\
\text { pre- and post-MW and } \\
\text { men }\end{array}$ & 21 studies of BMD & $\begin{array}{l}\text { Post-MW most at risk from } \\
\mathrm{T}_{4} \text {-suppressive treatment }\end{array}$ & $\begin{array}{l}\text { Heemstra et al. } \\
\text { (2006) }\end{array}$ \\
\hline 2006 & $\begin{array}{l}\text { Cross-sectional } \\
\text { study }\end{array}$ & $\begin{array}{l}\text { Women and men (Tromsø } \\
\text { study) }\end{array}$ & 27159 & $\begin{array}{l}\text { Increased risk of fracture associated } \\
\text { with TTX in men and women }\end{array}$ & Ahmed et al. (2006) \\
\hline 2011 & $\begin{array}{l}\text { Retrospective } \\
\text { cohort }\end{array}$ & $\begin{array}{l}\text { Subclinical hyperthyroid- } \\
\text { ism in pre- and post-MW } \\
\text { and men (TEARS study) }\end{array}$ & 2004 & $\begin{array}{l}\text { Increased risk of fracture but not } \\
\text { correlated with TSH level }\end{array}$ & $\begin{array}{l}\text { Vadiveloo et al. } \\
\quad(2011)\end{array}$ \\
\hline \multicolumn{6}{|c|}{ Studies of normal euthyroid individuals } \\
\hline 2006 & $\begin{array}{l}\text { Cross-sectional } \\
\text { study }\end{array}$ & Post-MW & 959 individuals & $\begin{array}{l}\text { Low normal TSH associated with } \\
\text { reduced BMD }\end{array}$ & Kim et al. (2006) \\
\hline 2007 & $\begin{array}{l}\text { Cross-sectional } \\
\text { study }\end{array}$ & Post-MW & 581 individuals & $\begin{array}{l}\text { Low normal TSH associated with } \\
\text { an increased risk of osteoporosis }\end{array}$ & Morris (2007) \\
\hline 2008 & $\begin{array}{l}\text { Cross-sectional } \\
\text { study }\end{array}$ & $\begin{array}{l}\text { Women and men (Tromsø } \\
\text { study) }\end{array}$ & 1961 individuals & $\begin{array}{l}\text { TSH within the normal range not } \\
\text { associated with BMD }\end{array}$ & $\begin{array}{l}\text { Grimnes et al. } \\
\text { (2008) }\end{array}$ \\
\hline 2008 & $\begin{array}{l}\text { 8-year prospective } \\
\text { study }\end{array}$ & $\begin{array}{l}\text { Women and men over } 55 \\
\text { years old (Rotterdam } \\
\text { study) }\end{array}$ & 1151 individuals & $\begin{array}{l}\mathrm{FT}_{4} \text { and } \mathrm{TSH} \text { associated with } \mathrm{BMD} \\
\text { but not fracture }\end{array}$ & $\begin{array}{l}\text { van der Deure et al. } \\
\text { (2008) }\end{array}$ \\
\hline 2010 & $\begin{array}{l}\text { 6-year prospective } \\
\text { study }\end{array}$ & Post-MW (OPUS study) & 1278 individuals & $\begin{array}{l}\text { High normal } \mathrm{fT}_{3} \text { and } \mathrm{fT}_{4} \text { associated } \\
\text { with reduced BMD and an } \\
\text { increased risk of fracture }\end{array}$ & Murphy et al. (2010) \\
\hline 2011 & $\begin{array}{l}\text { Cross-sectional } \\
\text { study }\end{array}$ & Women and men & 2957 individuals & $\begin{array}{l}\text { High normal } \mathrm{fT}_{4} \text { associated with } \\
\text { reduced } \mathrm{BMD}\end{array}$ & Lin et al. (2011) \\
\hline 2011 & $\begin{array}{l}\text { Cross-sectional } \\
\text { study }\end{array}$ & Young men & 1677 individuals & $\begin{array}{l}\text { High normal } \mathrm{fT}_{3} \text { and } \mathrm{fT}_{4} \text { associated } \\
\text { with reduced } \mathrm{BMD}\end{array}$ & Roef et al. (2011) \\
\hline
\end{tabular}

Post-MW, postmenopausal women; pre-MW, pre-menopausal women; TTX, thyrotoxicosis; BMD, bone mineral density.

relative hypercalcaemia inhibits $\mathrm{PTH}$ secretion and reduces renal 1- $\alpha$-hydroxylation of $25(\mathrm{OH})$-vitamin $\mathrm{D}$. The increased metabolic clearance associated with thyrotoxicosis further reduces circulating $1,25(\mathrm{OH})_{2}$-vitamin D levels, which leads to decreased intestinal calcium and phosphate absorption together with increased faecal calcium losses. Furthermore, the reduced PTH results in increased urinary calcium loss and phosphate resorption. Thus, increased skeletal calcium 
mobilisation combined with reduced PTH and $1,25(\mathrm{OH})_{2-}$ vitamin $\mathrm{D}$ levels result in a significant negative calcium balance in hyperthyroidism (Murphy \& Williams 2004).

\section{Treatment of thyrotoxicosis}

The effects of pharmacological, surgical and radioactive iodine treatment of thyrotoxicosis on bone turnover markers, BMD and fracture risk have been investigated. Two prospective studies demonstrated that elevated bone resorption markers normalised within 1 month of commencing treatment (Siddiqi et al. 1997, Al-Shoumer et al. 2006) and a retrospective cohort study of 630 women treated with thyroidectomy and followed up for an average of 20 years showed no independent influence of hyperthyroidism or $\mathrm{T}_{4}$ replacement on fracture risk (Melton et al. 2000). Furthermore, a meta-analysis of 20 studies demonstrated that although BMD was reduced at diagnosis, it returned to the normal range within 5 years of treatment irrespective of the modality of treatment (Vestergaard \& Mosekilde 2003). Two subsequent studies suggested that BMD returns to normal within 3 years of treatment and increases as much as 4\% within the first year (Karga et al. 2004, Udayakumar et al. 2006). Despite the reported rapid improvement in bone turnover markers and BMD, very large population studies have indicated that the increased risk of fracture associated with thyrotoxicosis persists for at least 5 years after diagnosis and treatment (Vestergaard et al. 2005) and is associated with increased mortality (Franklyn et al. 1998).

In summary, juvenile hyperthyroidism is associated with accelerated skeletal development but may ultimately lead to short stature due to premature growth plate closure. In adults, thyrotoxicosis leads to high bone turnover, negative calcium balance and an increased risk of fragility fracture. Treatment of thyrotoxicosis results in the normalisation of bone turnover markers and BMD but an increased risk of fracture persists for 5 years following treatment.

\section{Endogenous subclinical hyperthyroidism}

Subclinical hyperthyroidism is defined as a suppressed TSH in the context of normal thyroid hormone concentrations. Small studies of patients with subclinical hyperthyroidism have reported conflicting results either describing normal (De Menis et al. 1992, Faber et al. 1994, Mudde et al. 1994, Gurlek and Gedik 1999, Lee et al. 2006) or elevated (Campbell et al. 1996, Kumeda et al. 2000, Tauchmanova et al. 2004, Belaya et al. 2007, Rosario 2008) bone turnover makers. Similarly, small studies of have found either no change (Foldes et al. 1993, Gurlek \& Gedik 1999, Ugur-Altun et al. 2003, Lee et al. 2006) or a small reduction in BMD (Tauchmanova et al. 2004, Rosario 2008) in pre-menopausal women with subclinical hyperthyroidism. By contrast, the majority of studies in postmenopausal women demonstrated a reduction in BMD (Foldes et al. 1993, Mudde et al. 1994, Tauchmanova et al. 2004, Lee et al. 2006, Belaya et al. 2007, Rosario 2008).
A large study that included 968 males and 993 postmenopausal women showed that a TSH below the $2 \cdot 5$ th percentile was associated with reduced BMD, although insufficient data are available to determine whether the individuals had subclinical or overt hyperthyroidism (Grimnes et al. 2008).

Two large population studies recently investigated the risk of fracture in subclinical hyperthyroidism. In a study of 2004 patients, subclinical hyperthyroidism was associated with an increased risk of fracture with a hazard ratio of $1 \cdot 25$. However, when patients who developed overt thyrotoxicosis or reverted to euthyroidism were excluded, this association was lost (Vadiveloo et al. 2011). In a prospective cohort study of adults over 65 years of age, men with endogenous subclinical hyperthyroidism had a hip fracture hazard ratio of 4.9 , whereas no clear association between subclinical hyperthyroidism and fracture was observed in postmenopausal women (Lee et al. 2010). Furthermore, studies by Bauer and Jamal have also reported an increased incidence of fracture in individuals with a TSH concentration suppressed below $0.5 \mathrm{mIU} / 1$ but insufficient data are available to determine whether the individuals had subclinical or overt hyperthyroidism (Bauer et al. 2001, Jamal et al. 2005). A limited number of small studies have investigated the effects of normalising TSH in individuals with endogenous subclinical hyperthyroidism. In a prospective study of 16 postmenopausal women, treatment with methimazole did not affect bone turnover markers but distal forearm BMD was increased by the second year of treatment (Mudde et al. 1994), and in a second study of 14 patients, skeletal parameters also improved following treatment (Buscemi et al. 2007). In a study of 16 postmenopausal women treated with radioactive iodine, BMD increased compared with untreated controls (Faber et al. 1998).

In summary, endogenous subclinical hyperthyroidism may be associated with an increased bone turnover, reduced BMD and increased fracture risk, although insufficient data are currently available to draw definitive conclusions. Overall, the evidence suggests a small reduction in BMD and an increased risk of fracture in postmenopausal women and in men but not in pre-menopausal women.

\section{Suppressive doses of $\mathrm{T}_{4}$ in differentiated thyroid cancer}

Patients with differentiated thyroid carcinoma are frequently treated for prolonged periods with doses of $\mathrm{T}_{4}$ sufficient to suppress the circulating TSH concentration. The effects of such long-term exogenous subclinical hyperthyroidism on bone turnover markers and BMD, at a number of anatomical locations, have been investigated in many small studies. In pre-menopausal women receiving suppressive doses of $\mathrm{T}_{4}$, 16 studies have reported bone turnover markers, with eight showing an increase and eight no change, while 29 studies have reported BMD with nine showing a decrease and 20 showing no change. Heemstra et al. (2006) analysed four 
prospective and 12 cross-sectional studies of pre-menopausal women receiving suppressive doses of $\mathrm{T}_{4}$, and concluded that treatment with suppressive doses of $\mathrm{T}_{4}$ did not affect BMD, although a full meta-analysis could not be performed due to heterogeneity. This conclusion was consistent with two preceding systematic literature reviews (Faber \& Galloe 1994, Uzzan et al. 1996, Quan et al. 2002, Murphy \& Williams 2004, Heemstra et al. 2006) and two meta-analyses (Faber \& Galloe 1994, Uzzan et al. 1996). Currently, there are no prospective data on fracture risk in pre-menopausal women receiving suppressive doses of $\mathrm{T}_{4}$. Nineteen studies have reported bone turnover markers in postmenopausal women receiving suppressive doses of $\mathrm{T}_{4}, 13$ reported an increase and six showed no change. Thirty studies have reported $\mathrm{BMD}$ in postmenopausal women receiving suppressive doses of $\mathrm{T}_{4}$ and 11 showed a decrease in BMD while 19 showed no change. Furthermore, the two most rigorous cross-sectional studies were also conflicting, with Franklyn et al. (1992) reporting no effect in 26 postmenopausal UK women treated for 8 years whereas Kung \& Yeung (1996) found reduced, lumbar spine and femoral BMD in 34 postmenopausal Asian women treated with suppressive doses of $T_{4}$. Of three systematic literature reviews, two concluded that skeletal effects of suppressive doses of $T_{4}$ in postmenopausal women remain uncertain (Quan et al. 2002, Murphy \& Williams 2004) and one concluded that postmenopausal women were the subgroup most at risk (Heemstra et al. 2006). Nevertheless, two reported metaanalyses have suggested that suppressive doses of $\mathrm{T}_{4}$ in postmenopausal women lead to increased bone loss of $\sim 1 \%$ per annum (Faber \& Galloe 1994, Uzzan et al. 1996). Eight studies have also included male patients, but only one reported a reduction of $\mathrm{BMD}$ in men receiving suppressive doses of $\mathrm{T}_{4}$ (Jodar et al. 1998). Consistent with this, a metaanalysis concluded that suppressive doses of $\mathrm{T}_{4}$ had no effect on BMD in men (Uzzan et al. 1996). Currently, no studies with sufficient statistical power to establish the effect of prolonged suppressive $T_{4}$ treatment on fracture risk have been reported. However, in a cross-sectional thyroid registry study of 1180 individuals on $\mathrm{T}_{4}$ replacement, $59 \%$ were found to have suppressed TSH but no increased risk of fracture risk was identified (Leese et al. 1992).

In summary, treatment with suppressive doses of $T_{4}$ does not affect $B M D$ in pre-menopausal women or men but may lead to reduced $B M D$ in postmenopausal women and the majority of recent studies recommend monitoring these patients. The effects on bone turnover markers remain uncertain and fracture risk has not been studied.

\section{Skeletal effects of thyroid hormone concentrations in the upper normal range}

Very few studies have investigated the relationship between bone turnover markers and circulating thyroid hormone concentrations within the euthyroid reference range. Zofkova \& Hill (2008) performed a small cross-sectional study in
60 postmenopausal women and reported a correlation between high circulating TSH and lower levels of bone resorption markers. By contrast, several larger studies have investigated the relationship between circulating thyroid hormone concentrations and BMD. Kim et al. (2006) studied 959 healthy postmenopausal Korean women and reported that a low normal TSH was associated with reduced lumbar spine and femoral neck BMD. Morris (2007) investigated 581 postmenopausal American women and reported that a low normal TSH was associated with a fivefold higher incidence of osteoporosis than a high normal TSH. In the Tromsø study of 993 postmenopausal women and 968 men, individuals with a TSH above the $97 \cdot 5$ th percentile had increased femoral neck BMD, whereas those with a TSH below the $2 \cdot 5$ th percentile had reduced forearm BMD but no association was found between BMD and TSH within the normal range (Grimnes et al. 2008). In the Rotterdam study of 1151 euthyroid men and women aged over 55 years, femoral neck BMD correlated positively with TSH and negatively with $\mathrm{fT}_{4}$ (van der Deure et al. 2008). A recent large Taiwanese study of 2957 euthyroid healthy male and female individuals over 45 years of age again reported a negative correlation between BMD and $\mathrm{fT}_{4}$ but found no correlation with TSH (Lin et al. 2011). A cross-sectional study of 677 healthy young men studied at the time of peak bone mass (25-45 years) reported that higher concentrations of $\mathrm{fT}_{3}$ and

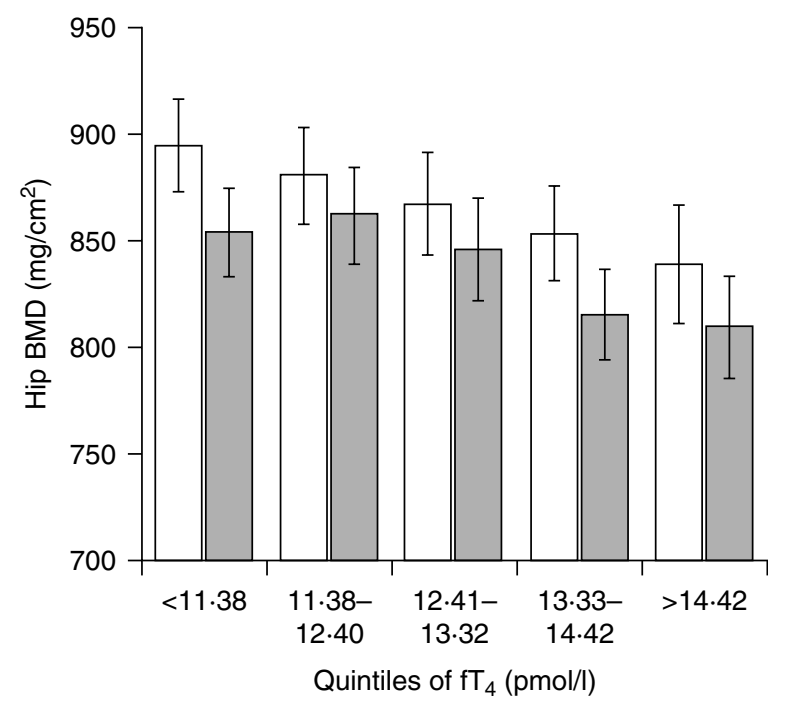

Figure 3 Effect of variation in $\mathrm{fT}_{4}$ concentration within the normal reference range on bone mineral density (BMD) in healthy euthyroid postmenopausal women from the Osteoporosis and Ultrasound Study (OPUS; Murphy et al. 2010). Graphs showing mean hip $B M D \pm 95 \%$ confidence intervals at the time of entry into the study (white bars) and after 6 years prospective follow-up (grey bars) in relation to quintiles of $\mathrm{fT}_{4}$ concentration. The $\mathrm{fT}_{4}$ reference range was determined in 1754 healthy postmenopausal women $\geq 55$ years old ( $\mathrm{fT}_{4}: 9 \cdot 15-16.99 \mathrm{pmol} / \mathrm{l}$ ). Individuals with $\mathrm{fT}_{4}$ levels in the highest quintile had lower hip BMD than women with $\mathrm{fT}_{4}$ in the lowest quintile at the time of entry into the study $(P=0 \cdot 02)$ and after 6 years of follow-up $(P=0 \cdot 04)$. 
$\mathrm{fT}_{4}$ were correlated with lower BMD (Roef et al. 2011). A limited number of studies have investigated the relationship between incident fracture and circulating thyroid hormone concentrations within the euthyroid reference range. A 10-year prospective study of 367 healthy postmenopausal women found no association between thyroid hormone concentrations and vertebral fracture (Finigan et al. 2008). Nevertheless, in a population of 130 euthyroid postmenopausal women with osteoporosis or osteopenia, Mazziotti et al. (2010) reported that a TSH in the lower third of the reference range was independently associated with an increased risk of vertebral fracture. Furthermore, a recent large 6-year prospective study of 1278 healthy euthyroid postmenopausal European women demonstrated that higher $\mathrm{fT}_{4}$ was associated with lower BMD and increasing bone loss at the hip (Fig. 3; Murphy et al. 2010). In addition, individuals in the highest quintile for $\mathrm{fT}_{4}$ and $\mathrm{fT}_{3}$ had a $20 \%$ and $33 \%$ increase in incident non-vertebral fracture respectively, whereas those in the highest quintile for TSH had a $35 \%$ reduction in fracture risk (Murphy et al. 2010).

In summary, these studies demonstrate that thyroid status at the upper end of the normal reference range is associated with lower BMD and increased fracture risk.

\section{Conclusions}

Thyroid hormone is a key regulator of skeletal development and adult bone maintenance, and thyroid hormone excess leads to detrimental effects in both the juvenile and adult skeleton. Detailed studies of a series of genetically modified mice have demonstrated that the actions of $\mathrm{T}_{3}$ in bone are predominantly mediated by $\mathrm{TR} \alpha 1$ and that $\mathrm{T}_{3}$ actions are anabolic during development but catabolic in adulthood. Thus, childhood thyrotoxicosis results in accelerated growth and advanced endochondral ossification, whereas in adults, hyperthyroidism leads to reduced BMD and an increased risk of fragility fracture due to accelerated bone remodelling and an excess of bone resorption compared with bone formation. The sensitivity of the adult skeleton to prolonged exposure to even small changes in thyroid status is illustrated by the reduction in BMD and the increase in fracture risk in postmenopausal women and men with subclinical hyperthyroidism and in postmenopausal women treated with suppressive doses of $\mathrm{T}_{4}$. Furthermore, recent studies have suggested that lifelong exposure to thyroid hormone levels in the upper normal reference range is associated with lower BMD and an increased risk of fracture risk when compared with individuals with a HPT axis set point in the lower normal reference range. Despite these important observations, the cellular and molecular mechanisms of thyroid hormone action in bone remain incompletely understood. While there are direct actions of $\mathrm{T}_{3}$ in chondrocytes and osteoblasts, evidence for such effects in osteoclasts remains controversial and it is unclear whether $\mathrm{T}_{3}$ acts directly or whether its actions in osteoclasts are indirect and mediated by osteoblasts. Furthermore, although a number of studies have suggested that TSH may directly inhibit bone turnover, other studies have been conflicting. Ultimately, these important questions will be resolved by conditional gene targeting of the chondrocyte, osteoblast and osteoclast lineages to identify which bone cells are directly responsive in vivo.

\section{Declaration of interest}

The authors declare that there is no conflict of interest that could be perceived as prejudicing the impartiality of the review reported.

\section{Funding}

This work was supported by a Medical Research Council (grant no. G800261, to J H D Bassett and G RWilliams) and a Sir Jules Thorn Scholarship (grant to J H D Bassett and J J Nicholls).

\section{References}

Abe E, Marians RC, Yu W, Wu XB, Ando T, Li Y, Iqbal J, Eldeiry L, Rajendren G, Blair HC et al. 2003 TSH is a negative regulator of skeletal remodeling. Cell 115 151-162. (doi:10.1016/S0092-8674(03)00771-2)

Abel ED, Ahima RS, Boers ME, Elmquist JK \& Wondisford FE 2001 Critical role for thyroid hormone receptor $\beta 2$ in the regulation of paraventricular thyrotropin-releasing hormone neurons. Journal of Clinical Investigation 107 1017-1023. (doi:10.1172/JCI10858)

Ahmed LA, Schirmer H, Berntsen GK, Fonnebo V \& Joakimsen RM 2006 Self-reported diseases and the risk of non-vertebral fractures: the Tromsø study. Osteoporosis International 17 46-53. (doi:10.1007/s00198005-1892-6)

Al-Shoumer KA, Vasanthy BA \& Al-Zaid MM 2006 Effects of treatment of hyperthyroidism on glucose homeostasis, insulin secretion, and markers of bone turnover. Endocrine Practice 12 121-130.

Allain TJ, Chambers TJ, Flanagan AM \& McGregor AM 1992 Triiodothyronine stimulates rat osteoclastic bone resorption by an indirect effect. Journal of Endocrinology 133 327-331. (doi:10.1677/joe.0.1330327)

Barnard JC, Williams AJ, Rabier B, Chassande O, Samarut J, Cheng SY, Bassett JH \& Williams GR 2005 Thyroid hormones regulate fibroblast growth factor receptor signaling during chondrogenesis. Endocrinology 146 5568-5580. (doi:10.1210/en.2005-0762)

Bassett JH \& Williams GR 2008 Critical role of the hypothalamic-pituitarythyroid axis in bone. Bone 43 418-426. (doi:10.1016/j.bone.2008.05.007)

Bassett JH \& Williams GR 2009 The skeletal phenotypes of TRalpha and TRbeta mutant mice. Journal of Molecular Endocrinology 42 269-282. (doi:10.1677/JME-08-0142)

Bassett JH, Swinhoe R, Chassande O, Samarut J \& Williams GR 2006 Thyroid hormone regulates heparan sulfate proteoglycan expression in the growth plate. Endocrinology 147 295-305. (doi:10.1210/en.2005-0485)

Bassett JH, Nordstrom K, Boyde A, Howell PG, Kelly S, Vennstrom B \& Williams GR 2007a Thyroid status during skeletal development determines adult bone structure and mineralization. Molecular Endocrinology 21 1893-1904. (doi:10.1210/me.2007-0157)

Bassett JH, O'Shea PJ, Sriskantharajah S, Rabier B, Boyde A, Howell PG, Weiss RE, Roux JP, Malaval L, Clement-Lacroix P et al. $2007 b$ Thyroid hormone excess rather than thyrotropin deficiency induces osteoporosis in hyperthyroidism. Molecular Endocrinology 21 1095-1107. (doi:10.1210/me. 2007-0033)

Bassett JH, Williams AJ, Murphy E, Boyde A, Howell PG, Swinhoe R, Archanco M, Flamant F, Samarut J, Costagliola S et al. 2008 A lack of 
thyroid hormones rather than excess thyrotropin causes abnormal skeletal development in hypothyroidism. Molecular Endocrinology 22 501-512. (doi:10.1210/me.2007-0221)

Bassett JH, Boyde A, Howell PG, Bassett RH, Galliford TM, Archanco M, Evans H, Lawson MA, Croucher P, St Germain DL et al. 2010 Optimal bone strength and mineralization requires the type 2 iodothyronine deiodinase in osteoblasts. PNAS 107 7604-7609. (doi:10.1073/pnas. 0911346107)

Bauer DC, Nevitt MC, Ettinger B \& Stone K 1997 Low thyrotropin levels are not associated with bone loss in older women: a prospective study. Journal of Clinical Endocrinology and Metabolism 82 2931-2936. (doi:10.1210/ jc.82.9.2931)

Bauer DC, Ettinger B, Nevitt MC \& Stone KL 2001 Risk for fracture in women with low serum levels of thyroid-stimulating hormone. Annals of Internal Medicine 134 561-568.

Belaya ZE, Melnichenko GA, Rozhinskaya LY, Fadeev VV, Alekseeva TM, Dorofeeva OK, Sasonova NI \& Kolesnikova GS 2007 Subclinical hyperthyroidism of variable etiology and its influence on bone in postmenopausal women. Hormones 6 62-70.

Bianco AC \& Kim BW 2006 Deiodinases: implications of the local control of thyroid hormone action. Journal of Clinical Investigation 116 2571-2579. (doi:10.1172/JCI29812)

Boersma B, Otten BJ, Stoelinga GB \& Wit JM 1996 Catch-up growth after prolonged hypothyroidism. European Journal of Pediatrics 155 362-367. (doi:10.1007/BF01955262)

Bookout AL, Jeong Y, Downes M, Yu RT, Evans RM \& Mangelsdorf DJ 2006 Anatomical profiling of nuclear receptor expression reveals a hierarchical transcriptional network. Cell 126 789-799. (doi:10.1016/ j.cell.2006.06.049)

Britto JM, Fenton AJ, Holloway WR \& Nicholson GC 1994 Osteoblasts mediate thyroid hormone stimulation of osteoclastic bone resorption. Endocrinology 134 169-176. (doi:10.1210/en.134.1.169)

Buscemi S, Verga S, Cottone S, Andronico G, D’Orio L, Mannino V, Panzavecchia D, Vitale F \& Cerasola G 2007 Favorable clinical heart and bone effects of anti-thyroid drug therapy in endogenous subclinical hyperthyroidism. Journal of Endocrinological Investigation 30 230-235.

Campbell J, Day P \& Diamond T 1996 Fine adjustments in thyroxine replacement and its effect on bone metabolism. Thyroid 6 75-78. (doi:10.1089/thy.1996.6.75)

Cheng SY, Leonard JL \& Davis PJ 2010 Molecular aspects of thyroid hormone actions. Endocrine Reviews 31 139-170. (doi:10.1210/er.2009-0007)

Cummings SR, Nevitt MC, Browner WS, Stone K, Fox KM, Ensrud KE, Cauley J, Black D \& Vogt TM 1995 Risk factors for hip fracture in white women. Study of Osteoporotic Fractures Research Group. New England Journal of Medicine 332 767-773. (doi:10.1056/NEJM199503233321202)

Davies T, Marians R \& Latif R 2002 The TSH receptor reveals itself. Journal of Clinical Investigation 110 161-164. (doi:10.1172/JCI16234)

De Menis E, Da Rin G, Roiter I, Legovini P, Foscolo G \& Conte N 1992 Bone turnover in overt and subclinical hyperthyroidism due to autonomous thyroid adenoma. Hormone Research 37 217-220. (doi:10.1159/000182315)

Dentice M, Bandyopadhyay A, Gereben B, Callebaut I, Christoffolete MA, Kim BW, Nissim S, Mornon JP, Zavacki AM, Zeold A et al. 2005 The Hedgehog-inducible ubiquitin ligase subunit WSB-1 modulates thyroid hormone activation and $\mathrm{PTHrP}$ secretion in the developing growth plate. Nature Cell Biology 7 698-705. (doi:10.1038/ncb1272)

van der Deure WM, Uitterlinden AG, Hofman A, Rivadeneira F, Pols HA, Peeters RP \& Visser TJ 2008 Effects of serum TSH and $\mathrm{FT}_{4}$ levels and the TSHR-Asp727Glu polymorphism on bone: the Rotterdam Study. Clinical Endocrinology 68 175-181. (doi:10.1111/j.1365-2265.2007.03016.x)

van der Deure WM, Peeters RP \& Visser TJ 2010 Molecular aspects of thyroid hormone transporters, including MCT8, MCT10, and OATPs, and the effects of genetic variation in these transporters. Journal of Molecular Endocrinology 44 1-11. (doi:10.1677/JME-09-0042)

Eriksen EF, Mosekilde L \& Melsen F 1986 Kinetics of trabecular bone resorption and formation in hypothyroidism: evidence for a positive balance per remodeling cycle. Bone 7 101-108. (doi:10.1016/87563282(86)90681-2)
Faber J \& Galloe AM 1994 Changes in bone mass during prolonged subclinical hyperthyroidism due to L-thyroxine treatment: a meta-analysis. European Journal of Endocrinology 130 350-356. (doi:10.1530/eje.0.1300350)

Faber J, Overgaard K, Jarlov AE \& Christiansen C 1994 Bone metabolism in premenopausal women with nontoxic goiter and reduced serum thyrotropin levels. Thyroidology 6 27-32.

Faber J, Jensen IW, Petersen L, Nygaard B, Hegedus L \& Siersbaek-Nielsen K 1998 Normalization of serum thyrotrophin by means of radioiodine treatment in subclinical hyperthyroidism: effect on bone loss in postmenopausal women. Clinical Endocrinology 48 285-290. (doi:10.1046/j. 1365-2265.1998.00427.x)

Finigan J, Greenfield DM, Blumsohn A, Hannon RA, Peel NF, Jiang G \& Eastell R 2008 Risk factors for vertebral and nonvertebral fracture over 10 years: a population-based study in women. Journal of Bone and Mineral Research 23 75-85. (doi:10.1359/jbmr.070814)

Foldes J, Tarjan G, Szathmari M, Varga F, Krasznai I \& Horvath C 1993 Bone mineral density in patients with endogenous subclinical hyperthyroidism: is this thyroid status a risk factor for osteoporosis? Clinical Endocrinology 39 521-527. (doi:10.1111/j.1365-2265.1993.tb02403.x)

Forrest D, Sjoberg M \& Vennstrom B 1990 Contrasting developmental and tissue-specific expression of alpha and beta thyroid hormone receptor genes. EMBO Journal 9 1519-1528.

Franklyn JA, Betteridge J, Daykin J, Holder R, Oates GD, Parle JV, Lilley J, Heath DA \& Sheppard MC 1992 Long-term thyroxine treatment and bone mineral density. Lancet 340 9-13. (doi:10.1016/0140-6736(92)92423-D)

Franklyn JA, Maisonneuve P, Sheppard MC, Betteridge J \& Boyle P 1998 Mortality after the treatment of hyperthyroidism with radioactive iodine. New England Journal of Medicine 338 712-718. (doi:10.1056/ NEJM199803123381103)

Garnero P, Vassy V, Bertholin A, Riou JP \& Delmas PD 1994 Markers of bone turnover in hyperthyroidism and the effects of treatment. Journal of Clinical Endocrinology and Metabolism 78 955-959. (doi:10.1210/jc.78.4.955)

Gauthier K, Plateroti M, Harvey CB, Williams GR, Weiss RE, Refetoff S, Willott JF, Sundin V, Roux JP, Malaval L et al. 2001 Genetic analysis reveals different functions for the products of the thyroid hormone receptor alpha locus. Molecular and Cellular Biology 21 4748-4760. (doi:10.1128/MCB.21. 14.4748-4760.2001)

Gereben B, Zavacki AM, Ribich S, Kim BW, Huang SA, Simonides WS, Zeold A \& Bianco AC 2008 Cellular and molecular basis of deiodinaseregulated thyroid hormone signaling. Endocrine Reviews 29 898-938. (doi:10.1210/er.2008-0019)

Giusti M, Cecoli F, Ghiara C, Rubinacci A, Villa I, Cavallero D, Mazzuoli L, Mussap M, Lanzi R \& Minuto F 2007 Recombinant human thyroid stimulating hormone does not acutely change serum osteoprotegerin and soluble receptor activator of nuclear factor- $\mathrm{\kappa B}$ ligand in patients under evaluation for differentiated thyroid carcinoma. Hormones 6 304-313.

Grimnes G, Emaus N, Joakimsen RM, Figenschau Y \& Jorde R 2008 The relationship between serum TSH and bone mineral density in men and postmenopausal women: the Tromsø study. Thyroid 18 1147-1155. (doi:10.1089/thy.2008.0158)

Guo CY, Weetman AP \& Eastell R 1997 Longitudinal changes of bone mineral density and bone turnover in postmenopausal women on thyroxine. Clinical Endocrinology 46 301-307. (doi:10.1046/j.1365-2265. 1997.1280950.x)

Gurlek A \& Gedik O 1999 Effect of endogenous subclinical hyperthyroidism on bone metabolism and bone mineral density in premenopausal women. Thyroid 9 539-543. (doi:10.1089/thy.1999.9.539)

Hansen PS, Brix TH, Sorensen TI, Kyvik KO \& Hegedus L 2004 Major genetic influence on the regulation of the pituitary-thyroid axis: a study of healthy Danish twins. Journal of Clinical Endocrinology and Metabolism 89 1181-1187. (doi:10.1210/jc.2003-031641)

Harvey CB \& Williams GR 2002 Mechanism of thyroid hormone action. Thyroid 12 441-446. (doi:10.1089/105072502760143791)

Harvey RD, McHardy KC, Reid IW, Paterson F, Bewsher PD, Duncan A \& Robins SP 1991 Measurement of bone collagen degradation in 
hyperthyroidism and during thyroxine replacement therapy using pyridinium cross-links as specific urinary markers. Journal of Clinical Endocrinology and Metabolism 72 1189-1194. (doi:10.1210/jcem-72-6-1189)

Hase H, Ando T, Eldeiry L, Brebene A, Peng Y, Liu L, Amano H, Davies TF, Sun L, Zaidi M et al. 2006 TNFalpha mediates the skeletal effects of thyroid-stimulating hormone. PNAS 103 12849-12854. (doi:10.1073/ pnas.0600427103)

Heemstra KA, Hamdy NA, Romijn JA \& Smit JW 2006 The effects of thyrotropin-suppressive therapy on bone metabolism in patients with welldifferentiated thyroid carcinoma. Thyroid 16 583-591. (doi:10.1089/thy. 2006.16.583)

Heino TJ, Hentunen TA \& Vaananen HK 2002 Osteocytes inhibit osteoclastic bone resorption through transforming growth factor-beta: enhancement by estrogen. Journal of Cellular Biochemistry 85 185-197. (doi:10.1002/jcb.10109)

Himeno M, Enomoto H, Liu W, Ishizeki K, Nomura S, Kitamura Y \& Komori T 2002 Impaired vascular invasion of Cbfa1-deficient cartilage engrafted in the spleen. Journal of Bone and Mineral Research 17 1297-1305. (doi:10.1359/jbmr.2002.17.7.1297)

Huang BK, Golden LA, Tarjan G, Madison LD \& Stern PH 2000 Insulin-like growth factor I production is essential for anabolic effects of thyroid hormone in osteoblasts. Journal of Bone and Mineral Research 15 188-197. (doi:10.1359/jbmr.2000.15.2.188)

Huffmeier U, Tietze HU \& Rauch A 2007 Severe skeletal dysplasia caused by undiagnosed hypothyroidism. European Journal of Medical Genetics $\mathbf{5 0}$ 209-215. (doi:10.1016/j.ejmg.2007.02.002)

Ishikawa Y, Genge BR, Wuthier RE \& Wu LN 1998 Thyroid hormone inhibits growth and stimulates terminal differentiation of epiphyseal growth plate chondrocytes. Journal of Bone and Mineral Research 13 1398-1411. (doi:10.1359/jbmr.1998.13.9.1398)

Jamal SA, Leiter RE, Bayoumi AM, Bauer DC \& Cummings SR 2005 Clinical utility of laboratory testing in women with osteoporosis. Osteoporosis International 16 534-540. (doi:10.1007/s00198-004-1718-y)

Jodar E, Begona Lopez M, Garcia L, Rigopoulou D, Martinez G \& Hawkins F 1998 Bone changes in pre- and postmenopausal women with thyroid cancer on levothyroxine therapy: evolution of axial and appendicular bone mass. Osteoporosis International 8 311-316. (doi:10.1007/s001980050069)

Kanatani M, Sugimoto T, Sowa H, Kobayashi T, Kanzawa M \& Chihara K 2004 Thyroid hormone stimulates osteoclast differentiation by a mechanism independent of RANKL-RANK interaction. Journal of Cellular Physiology 201 17-25. (doi:10.1002/jcp.20041)

Karga H, Papapetrou PD, Korakovouni A, Papandroulaki F, Polymeris A \& Pampouras G 2004 Bone mineral density in hyperthyroidism. Clinical Endocrinology 61 466-472. (doi:10.1111/j.1365-2265.2004.02110.x)

Karga H, Papaioannou G, Polymeris A, Papamichael K, Karpouza A, Samouilidou E \& Papaioannou P 2010 The effects of recombinant human TSH on bone turnover in patients after thyroidectomy. Journal of Bone and Mineral Metabolism 28 35-41. (doi:10.1007/s00774-009-0098-y)

Kim DJ, Khang YH, Koh JM, Shong YK \& Kim GS 2006 Low normal TSH levels are associated with low bone mineral density in healthy postmenopausal women. Clinical Endocrinology 64 86-90. (doi:10.1111/j. 1365-2265.2005.02422.x)

Kumeda $\mathrm{Y}$, Inaba $\mathrm{M}$, Tahara $\mathrm{H}$, Kurioka $\mathrm{Y}$, Ishikawa T, Morii $\mathrm{H} \&$ Nishizawa Y 2000 Persistent increase in bone turnover in Graves' patients with subclinical hyperthyroidism. Journal of Clinical Endocrinology and Metabolism 85 4157-4161. (doi:10.1210/jc.85.11.4157)

Kung AW \& Yeung SS 1996 Prevention of bone loss induced by thyroxine suppressive therapy in postmenopausal women: the effect of calcium and calcitonin. Journal of Clinical Endocrinology and Metabolism 81 1232-1236. (doi:10.1210/jc.81.3.1232)

Lassova L, Niu Z, Golden EB, Cohen AJ \& Adams SL 2009 Thyroid hormone treatment of cultured chondrocytes mimics in vivo stimulation of collagen $\mathrm{X}$ mRNA by increasing BMP 4 expression. Journal of Cellular Physiology 219 595-605. (doi:10.1002/jcp.21704)

Lee WY, Oh KW, Rhee EJ, Jung CH, Kim SW, Yun EJ, Tae HJ, Baek KH, Kang MI, Choi MG et al. 2006 Relationship between subclinical thyroid dysfunction and femoral neck bone mineral density in women. Archives of Medical Research 37 511-516. (doi:10.1016/j.arcmed.2005.09.009)
Lee JS, Buzkova P, Fink HA, Vu J, Carbone L, Chen Z, Cauley J, Bauer DC, Cappola AR \& Robbins J 2010 Subclinical thyroid dysfunction and incident hip fracture in older adults. Archives of Internal Medicine $\mathbf{1 7 0}$ 1876-1883. (doi:10.1001/archinternmed.2010.424)

Leese GP, Jung RT, Guthrie C, Waugh N \& Browning MC 1992 Morbidity in patients on L-thyroxine: a comparison of those with a normal TSH to those with a suppressed TSH. Clinical Endocrinology 37 500-503. (doi:10.1111/j. 1365-2265.1992.tb01480.x)

Lin JD, Pei D, Hsia TL, Wu CZ, Wang K, Chang YL, Hsu CH, Chen YL, Chen KW \& Tang SH 2011 The relationship between thyroid function and bone mineral density in euthyroid healthy subjects in Taiwan. Endocrine Research 36 1-8. (doi:10.3109/07435800.2010.514877)

Ma R, Morshed S, Latif R, Zaidi M \& Davies TF 2011 The influence of thyroid-stimulating hormone and thyroid-stimulating hormone receptor antibodies on osteoclastogenesis. Thyroid 21 897-906. (doi:10.1089/thy. 2010.0457)

Makihira S, Yan W, Murakami H, Furukawa M, Kawai T, Nikawa H, Yoshida E, Hamada T, Okada Y \& Kato Y 2003 Thyroid hormone enhances aggrecanase-2/ADAM-TS5 expression and proteoglycan degradation in growth plate cartilage. Endocrinology 144 2480-2488. (doi:10.1210/en.2002-220746)

Martini G, Gennari L, De Paola V, Pilli T, Salvadori S, Merlotti D, Valleggi F, Campagna S, Franci B, Avanzati A et al. 2008 The effects of recombinant TSH on bone turnover markers and serum osteoprotegerin and RANKL levels. Thyroid 18 455-460. (doi:10.1089/thy.2007.0166)

Mazziotti G, Sorvillo F, Piscopo M, Cioffi M, Pilla P, Biondi B, Iorio S, Giustina A, Amato G \& Carella C 2005 Recombinant human TSH modulates in vivo C-telopeptides of type-1 collagen and bone alkaline phosphatase, but not osteoprotegerin production in postmenopausal women monitored for differentiated thyroid carcinoma. Journal of Bone and Mineral Research 20 480-486. (doi:10.1359/JBMR.041126)

Mazziotti G, Porcelli T, Patelli I, Vescovi PP \& Giustina A 2010 Serum TSH values and risk of vertebral fractures in euthyroid post-menopausal women with low bone mineral density. Bone 46 747-751. (doi:10.1016/j.bone. 2009.10.031)

Medici M, van der Deure WM, Verbiest M, Vermeulen SH, Hansen PS, Kiemeney LA, Hermus AR, Breteler MM, Hofman A, Hegedus L et al. 2011 A large-scale association analysis of 68 thyroid hormone pathway genes with serum TSH and $\mathrm{FT}_{4}$ levels. European Journal of Endocrinology 164 781-788. (doi:10.1530/EJE-10-1130)

Melsen F \& Mosekilde L 1980 Trabecular bone mineralization lag time determined by tetracycline double-labeling in normal and certain pathological conditions. Acta Pathologica et Microbiologica Scandinavica. Section A, Pathology 88 83-88.

Melton LJ III, Ardila E, Crowson CS, O'Fallon WM \& Khosla S 2000 Fractures following thyroidectomy in women: a population-based cohort study. Bone 27 695-700. (doi:10.1016/S8756-3282(00)00379-3)

Morris MS 2007 The association between serum thyroid-stimulating hormone in its reference range and bone status in postmenopausal American women. Bone 40 1128-1134. (doi:10.1016/j.bone.2006.12.001)

Mosekilde L \& Melsen F 1978 A tetracycline-based histomorphometric evaluation of bone resorption and bone turnover in hyperthyroidism and hyperparathyroidism. Acta Medica Scandinavica 204 97-102. (doi:10.1111/j. 0954-6820.1978.tb08406.x)

Mosekilde L, Eriksen EF \& Charles P 1990 Effects of thyroid hormones on bone and mineral metabolism. Endocrinology and Metabolism Clinics of North America 19 35-63.

Mudde AH, Houben AJ \& Nieuwenhuijzen Kruseman AC 1994 Bone metabolism during anti-thyroid drug treatment of endogenous subclinical hyperthyroidism. Clinical Endocrinology 41 421-424. (doi:10.1111/j.13652265.1994.tb02571.x)

Mundy GR, Shapiro JL, Bandelin JG, Canalis EM \& Raisz LG 1976 Direct stimulation of bone resorption by thyroid hormones. Journal of Clinical Investigation 58 529-534. (doi:10.1172/JCI108497)

Murphy E \& Williams GR 2004 The thyroid and the skeleton. Clinical Endocrinology 61 285-298. (doi:10.1111/j.1365-2265.2004.02053.x)

Murphy E, Gluer CC, Reid DM, Felsenberg D, Roux C, Eastell R \& Williams GR 2010 Thyroid function within the upper normal range is 
associated with reduced bone mineral density and an increased risk of nonvertebral fractures in healthy euthyroid postmenopausal women. Journal of Clinical Endocrinology and Metabolism 95 3173-3181. (doi:10.1210/ jc.2009-2630)

Nakashima T, Hayashi M, Fukunaga T, Kurata K, Oh-Hora M, Feng JQ, Bonewald LF, Kodama T, Wutz A, Wagner EF et al. 2011 Evidence for osteocyte regulation of bone homeostasis through RANKL expression. Nature Medicine 17 1231-1234. (doi:10.1038/nm.2452)

O'Shea PJ, Harvey CB, Suzuki H, Kaneshige M, Kaneshige K, Cheng SY \& Williams GR 2003 A thyrotoxic skeletal phenotype of advanced bone formation in mice with resistance to thyroid hormone. Molecular Endocrinology 17 1410-1424. (doi:10.1210/me.2002-0296)

O'Shea PJ, Bassett JH, Sriskantharajah S, Ying H, Cheng SY \& Williams GR 2005 Contrasting skeletal phenotypes in mice with an identical mutation targeted to thyroid hormone receptor alpha1 or beta. Molecular Endocrinology 19 3045-3059. (doi:10.1210/me.2005-0224)

Panicker V, Wilson SG, Spector TD, Brown SJ, Falchi M, Richards JB, Surdulescu GL, Lim EM, Fletcher SJ \& Walsh JP 2008a Heritability of serum TSH, free $\mathrm{T}_{4}$ and free $\mathrm{T}_{3}$ concentrations: a study of a large UK twin cohort. Clinical Endocrinology 68 652-659. (doi:10.1111/j.1365-2265.2007. 03079.x)

Panicker V, Wilson SG, Spector TD, Brown SJ, Kato BS, Reed PW, Falchi M, Richards JB, Surdulescu GL, Lim EM et al. $2008 b$ Genetic loci linked to pituitary-thyroid axis set points: a genome-wide scan of a large twin cohort. Journal of Clinical Endocrinology and Metabolism 93 3519-3523. (doi:10.1210/jc.2007-2650)

Papadimitriou A, Papadimitriou DT, Papadopoulou A, Nicolaidou P \& Fretzayas A 2007 Low TSH levels are not associated with osteoporosis in childhood. European Journal of Endocrinology 157 221-223. (doi:10.1530/ EJE-07-0247)

Parle JV, Franklyn JA, Cross KW, Jones SR \& Sheppard MC 1993 Thyroxine prescription in the community: serum thyroid stimulating hormone level assays as an indicator of undertreatment or overtreatment. British Journal of General Practice 43 107-109.

Plateroti M, Gauthier K, Domon-Dell C, Freund JN, Samarut J \& Chassande O 2001 Functional interference between thyroid hormone receptor alpha (TRalpha) and natural truncated TRDeltaalpha isoforms in the control of intestine development. Molecular and Cellular Biology 21 4761-4772. (doi:10.1128/MCB.21.14.4761-4772.2001)

Quan ML, Pasieka JL \& Rorstad O 2002 Bone mineral density in welldifferentiated thyroid cancer patients treated with suppressive thyroxine: a systematic overview of the literature. Journal of Surgical Oncology 79 62-69. (doi:10.1002/jso.10043)

Raggatt LJ \& Partridge NC 2010 Cellular and molecular mechanisms of bone remodeling. Journal of Biological Chemistry 285 25103-25108. (doi:10.1074/ jbc.R109.041087)

von Recklinghausen FC 1891 Die Fibrose oder deformirende ostitis, die osteomalacie und die osteoplastische carcinose in ihren gegenseitigen beziehungen. In Festschrift Rudolpf Virchow, pp 1-89. Ed. G Reimer. Berlin, 1891.

Rivkees SA, Bode HH \& Crawford JD 1988 Long-term growth in juvenile acquired hypothyroidism: the failure to achieve normal adult stature. New England Journal of Medicine 318 599-602. (doi:10.1056/ NEJM198803103181003)

Robson H, Siebler T, Stevens DA, Shalet SM \& Williams GR 2000 Thyroid hormone acts directly on growth plate chondrocytes to promote hypertrophic differentiation and inhibit clonal expansion and cell proliferation. Endocrinology 141 3887-3897. (doi:10.1210/en.141.10.3887)

Roef G, Lapauw B, Goemaere S, Zmierczak H, Fiers T, Kaufman JM \& Taes Y 2011 Thyroid hormone status within the physiological range affects bone mass and density in healthy men at the age of peak bone mass. European Journal of Endocrinology 164 1027-1034. (doi:10.1530/ EJE-10-1113)

Rosario PW 2008 Bone and heart abnormalities of subclinical hyperthyroidism in women below the age of 65 years. Arquivos Brasileiros de Endocrinologia e Metabologia 52 1448-1451. (doi:10.1590/S000427302008000900007)
Sampath TK, Simic P, Sendak R, Draca N, Bowe AE, O'Brien S, Schiavi SC, McPherson JM \& Vukicevic S 2007 Thyroid-stimulating hormone restores bone volume, microarchitecture, and strength in aged ovariectomized rats. Journal of Bone and Mineral Research 22 849-859. (doi:10.1359/jbmr.070302)

Seeley DG, Kelsey J, Jergas M \& Nevitt MC 1996 Predictors of ankle and foot fractures in older women. The Study of Osteoporotic Fractures Research Group. Journal of Bone and Mineral Research 11 1347-1355. (doi:10.1002/ jbmr.5650110920)

Segni M, Leonardi E, Mazzoncini B, Pucarelli I \& Pasquino AM 1999 Special features of Graves' disease in early childhood. Thyroid 9 871-877. (doi:10.1089/thy.1999.9.871)

Siddiqi A, Burrin JM, Noonan K, James I, Wood DF, Price CP \& Monson JP 1997 A longitudinal study of markers of bone turnover in Graves' disease and their value in predicting bone mineral density. Journal of Clinical Endocrinology and Metabolism 82 753-759. (doi:10.1210/jc.82.3.753)

Stevens DA, Hasserjian RP, Robson H, Siebler T, Shalet SM \& Williams GR 2000 Thyroid hormones regulate hypertrophic chondrocyte differentiation and expression of parathyroid hormone-related peptide and its receptor during endochondral bone formation. Journal of Bone and Mineral Research 15 2431-2442. (doi:10.1359/jbmr.2000.15.12.2431)

Stevens DA, Harvey CB, Scott AJ, O'Shea PJ, Barnard JC, Williams AJ, Brady G, Samarut J, Chassande O \& Williams GR 2003 Thyroid hormone activates fibroblast growth factor receptor-1 in bone. Molecular Endocrinology 17 1751-1766. (doi:10.1210/me.2003-0137)

St Germain DL, Galton VA \& Hernandez A 2009 Minireview: defining the roles of the iodothyronine deiodinases: current concepts and challenges. Endocrinology 150 1097-1107. (doi:10.1210/en.2008-1588)

Sun L, Vukicevic S, Baliram R, Yang G, Sendak R, McPherson J, Zhu LL, Iqbal J, Latif R, Natrajan A et al. 2008 Intermittent recombinant TSH injections prevent ovariectomy-induced bone loss. PNAS 105 4289-4294. (doi:10.1073/pnas.0712395105)

Tauchmanova L, Nuzzo V, Del Puente A, Fonderico F, Esposito-Del Puente A, Padulla S, Rossi A, Bifulco G, Lupoli G \& Lombardi G 2004 Reduced bone mass detected by bone quantitative ultrasonometry and DEXA in pre- and postmenopausal women with endogenous subclinical hyperthyroidism. Maturitas 48 299-306. (doi:10.1016/j. maturitas.2004.02.017)

Toivonen J, Tahtela R, Laitinen K, Risteli J \& Valimaki MJ 1998 Markers of bone turnover in patients with differentiated thyroid cancer with and following withdrawal of thyroxine suppressive therapy. European Journal of Endocrinology 138 667-673. (doi:10.1530/eje.0.1380667)

Tsai JA, Janson A, Bucht E, Kindmark H, Marcus C, Stark A, Zemack HR \& Torring O 2004 Weak evidence of thyrotropin receptors in primary cultures of human osteoblast-like cells. Calcified Tissue International 74 486-491. (doi:10.1007/s00223-003-0108-3)

Udayakumar N, Chandrasekaran M, Rasheed MH, Suresh RV \& Sivaprakash S 2006 Evaluation of bone mineral density in thyrotoxicosis. Singapore Medical Journal 47 947-950.

Ugur-Altun B, Altun A, Arikan E, Guldiken S \& Tugrul A 2003 Relationships existing between the serum cytokine levels and bone mineral density in women in the premenopausal period affected by Graves' disease with subclinical hyperthyroidism. Endocrine Research 29 389-398. (doi:10.1081/ERC-120026945)

Uzzan B, Campos J, Cucherat M, Nony P, Boissel JP \& Perret GY 1996 Effects on bone mass of long term treatment with thyroid hormones: a meta-analysis. Journal of Clinical Endocrinology and Metabolism 81 4278-4289. (doi:10.1210/jc.81.12.4278)

Vadiveloo T, Donnan PT, Cochrane L \& Leese GP 2011 The Thyroid Epidemiology, Audit, and Research Study (TEARS): morbidity in patients with endogenous subclinical hyperthyroidism. Journal of Clinical Endocrinology and Metabolism 96 1344-1351. (doi:10.1210/jc.20102693)

Vestergaard P \& Mosekilde L 2002 Fractures in patients with hyperthyroidism and hypothyroidism: a nationwide follow-up study in 16,249 patients. Thyroid 12 411-419. (doi:10.1089/105072502760043503) 
Vestergaard P \& Mosekilde L 2003 Hyperthyroidism, bone mineral, and fracture risk - a meta-analysis. Thyroid 13 585-593. (doi:10.1089/ 105072503322238854)

Vestergaard P, Rejnmark L \& Mosekilde L 2005 Influence of hyper- and hypothyroidism, and the effects of treatment with antithyroid drugs and levothyroxine on fracture risk. Calcified Tissue International 77 139-144. (doi:10.1007/s00223-005-0068-x)

Wang L, Shao YY \& Ballock RT 2010 Thyroid hormone-mediated growth and differentiation of growth plate chondrocytes involves IGF-1 modulation of beta-catenin signaling. Journal of Bone and Mineral Research 25 1138-1146. (doi:10.1002/jbmr.5)

Wejda B, Hintze G, Katschinski B, Olbricht T \& Benker G 1995 Hip fractures and the thyroid: a case-control study. Journal of Internal Medicine 237 241-247. (doi:10.1111/j.1365-2796.1995.tb01172.x)

Williams GR \& Bassett JH 2011 Deiodinases: the balance of thyroid hormone: local control of thyroid hormone action: role of type 2 deiodinase. Journal of Endocrinology 209 261-272. (doi:10.1530/ JOE-10-0448)
Xing W, Govoni K, Donahue LR, Kesavan C, Wergedal J, Long C, Bassett JH, Gogakos A, Wojcicka A, Williams GR et al. 2012 Genetic evidence that thyroid hormone is indispensable for prepubertal IGF-I expression and bone acquisition in mice. Journal of Bone and Mineral Research. In press. (doi:10.1002/jbmr.1551)

Yen PM 2001 Physiological and molecular basis of thyroid hormone action. Physiological Reviews 81 1097-1142.

Zofkova I \& Hill M 2008 Biochemical markers of bone remodeling correlate negatively with circulating TSH in postmenopausal women. Endocrine Regulations 42 121-127.

Received in final form 26 March 2012

Accepted 27 March 2012

Made available online as an Accepted Preprint 27 March 2012 